\title{
A Study on the Relationship between Climate Change and Peak Discharge in Sarawak River Basin
}

\author{
S.Y. Chiew, O.S. Selaman, and N.R. Afshar
}

\begin{abstract}
These Earth's climate is getting warmer, and the signs are everywhere. Abnormal river discharge is one of the impacts that can be found in local scale. This endangering condition leads to the necessary attention on river basin in Sarawak, Malaysia and hence gives birth to this study. The objective of this study is to examine the existence of climate change on Sungai Sarawak River Basin through a hydrologic analysis of river discharge of three water level stations: Station Rayu, Station Git and Station Buan Bidi. The methods applied are mass-curve coupled with Gumbel's graphical statistical method and annual hydrograph. Mass curve plotted shows the deviation of cumulative peak discharge from its original trend with Stations Rayu, Git and Buan Bidi started straying since years 1998, 2001 and 2004 respectively. After breakpoint, Gumbel's graphical statistical method for chance percent evaluation clearly implies the chance percent for all (exception for Station Buan Bidi) discharges has decreased throughout the years. Whereas Gumbel's graphical statistical method for return period evaluation suggested an extension of return period after the transition year (exception for Station Rayu). Two graphical methods pointed to the same direction - rate of decline shifting is greater for high flow as compared to low flow. Broadly speaking, precipitation has not much effect on the discharge variation according to annual hydrographs plotted. However, an obvious decrease in monthly average discharge throughout 18 years was found after change at Station Rayu. This support the climate change fact of "dry getting drier". Water shrinkage in Sarawak River Basin is expected to be experienced frequently in the future.
\end{abstract}

Keywords: peak discharge, climate change, mass-curve, Gumbel's statistical method, annual hydrograph

\section{INTRODUCTION}

MPACT of climate change is extending and even getting more serious to cope with. Potential impacts are varied in aspects; flood is one of them on hydrosphere. Some serious floods experienced in Malaysia are in the years of 1926, 1963, 1965, 1967, 1969, 1971, 1973, 1979, 1983, 1988 1993, 1998, 2003, 2004, 2005, 2006 and 2007 [1]. As there is no exception for flood visitation in Sarawak, Sungai Sarawak basin is selected as the study site to start with. Sungai Sarawak basin is one of the 22 major river basins in Sarawak. The river has a length of $120 \mathrm{~km}$ and basin area of 2,459 $\mathrm{km} 2$ [2]. It has two main tributaries: Sg Sarawak Kiri and Sg Sarawak Kanan.

The worst flood event in Sarawak's history occurred in the year 1963, where Siniawan, Batu Kitang and Batu Kawa recorded the maximum river water level. Satok Bridge recorded the maximum level in the 2004 flood event. In order to find out the involvement of climate change on public-worrying flooding in Sarawak, this analytical research pin pointed on Sarawak River Basin has been carried out. The main objective is to study the correlation between climate change and peak discharge at Sarawak River Basin.

\section{LITERATURE REVIEW}

Evidence for the state of climate continues to accumulate, strengthening the link between man's activity and a wide range of indicators of a changing climate, both globally and regionally. Reference [3] has compiled a set of 25 indicators tracking signs of climate change (see Table 1).

S.Y. Chiew is with the Department of Civil Engineering, Faculty of Engineering, Universiti Malaysia Sarawak, 94300 Kota Samarahan, Sarawak, Malaysia (e-mail: csy@hotmail.com).

O.S. Selaman is with the Department of Civil Engineering, Faculty of Engineering, Universiti Malaysia Sarawak, 94300 Kota Samarahan, Sarawak, Malaysia ( e-mail: sosuhaiza@feng.unimas.my).

N.R Afshar is with the Department of Civil Engineering, Faculty of Engineering, Universiti Malaysia Sarawak, 94300 Kota Samarahan, Sarawak, Malaysia (e-mail: anrostam@feng.unimas.my). 
UNIMAS e-Journal of Civil Engineering: Volume 4, Issue 3

Table 1: Indicators of Climate Change [3]

\begin{tabular}{ccccc}
\hline Greenhouse Gases & Weather and Climate & Oceans & Snow and Ice & Society and Ecosystems \\
\hline Greenhouse Gas & Global Temperature & Ocean Heat & Arctic Sea Ice & Streamflow \\
Emissions & High and Low & Sea Surface & Glaciers & Ragweed Pollen Season \\
$\begin{array}{c}\text { Atmospheric } \\
\text { Concentrations of }\end{array}$ & Temperatures & Temperature & & \\
Greenhouse Gases & Global Precipitation & Sea Level & Lake Ice & Length of Growing Season \\
Climate Forcing & Heavy Precipitation & Ocean Acidity & Snowfall & Leaf and Bloom Dates \\
- & Drought & - & Snow Cover & Bird Wintering Ranges \\
- & Tropical Cyclone Activity & - & Snowpack & Heat-Related Deaths \\
\hline
\end{tabular}

Primary indicator - temperature increases in summer have a negative effect on streamflow, while temperature increases in winter have a very small negative or slightly positive effect on streamflow. Other than temperature, sensitivity of streamflow to precipitation also varies between high-flow and low-flow rates. Higher discharge in streams is much more sensitive to amounts of precipitation received in each season than lower discharge. Consequently, variations in precipitation amounts would change high flows more than low flows in all seasons [3].

Study on drivers of streamflow variation is a complicated work because it is affected by both natural and human factors and can respond rapidly to changes in flow parameters. The consistency across different lines of evidence makes a strong case for a significant human influence on observed warming at the surface [4]. Numerous human activities on hydrosphere (damming, land-use practices, interbasin water transfers and etc.) have the potential to alter the supply of water and sediment to streams [5]. Some impacts of human involvement on streamflow are notified [10] - [11]. Nevertheless, natural disturbance effects, and ecosystem processes complicate, mitigate, and potentially also counteract the climate effects on streamflow [6]. In local scale, some natural based discharge variables are topography (upland relief), distance to sea, coverage of forests and mires, ground elevation, monsoon rainfall, and channel adjustment. References [12] - [14] have showed two natural factors topography and rate of submergence which have brought variation of streamflow in their studies.

A practical model usually considers only one or two sources of variation [7]. In practical, interactions in the global climate system are so complicated and wide ranging that computer models which try to mathematically simulate the climate system have been developed. It was agreed by statisticians that, floods of small frequency are random variables and they argue that even the highest design floods are strictly random variables and should be treated as elements of statistics of extremes [8]. For measure tool, researchers always go for flood frequency analysis which is based on determination by Gumbel's statistical or probability method. It is assumed to be independent and identically distributed, and the hydrologic system producing them is considered to be stochastic, space-independent, and time-independent.

\section{MATERIALS AND METHODS}

Annual maximum series which satisfied the assumptions of independence and identical distribution are collected for analysis in this case study [6]. Water level data acquired from DID branch in Kota Saramahan are converted into discharge by using rating curve equation. Details of three selected water level stations in the basin are as shown in Table 2 .

Table 2: Details of Selected Stations (Source: Sarawak Hydrological Year Book 2007)

\begin{tabular}{ccccc}
\hline $\begin{array}{c}\text { Station } \\
\text { Name }\end{array}$ & $\begin{array}{c}\text { Length of Period } \\
\text { Recorded }\end{array}$ & $\begin{array}{c}\text { Duration } \\
\text { (Years) }\end{array}$ & Rating Curve Equation & Effective Range \\
\hline Rayu & $1992-2009$ & 18 & $\mathrm{Q}=5.82(\mathrm{H}-0.20)^{\wedge} 4.34$ & $0.72-1.62 \mathrm{~m}$ \\
Git & $1990-2007$ & 18 & $\mathrm{Q}=21.42(\mathrm{H}-1.35)^{\wedge} 1.45$ & $1.72-10.32 \mathrm{~m}$ \\
Buan Bidi & $1990-2010$ & 21 & $\mathrm{Q}=13.18(\mathrm{H}-0.00)^{\wedge} 1.55$ & $0.28-4.81 \mathrm{~m}$ \\
\hline
\end{tabular}

Cooperation of mass curve method with probability distributions and annual hydrograph in assessing the existence of climate change on peak discharge variation across the historical years are applied. Mass curves with cumulative of annual peak streamflow versus years are plotted to estimate changes in regression slope. This method can smooth a time series and suppress random elements in the series, and thus shows the main trends of the time series. Reviewing the aim of this research, statistical method is selected focusing on simulating the past flow records in order to study movement trend in the past. Chance percent and return period are those parameters selected in this method. Return period is a measuring tool for the frequency of a peak flow event and chance percent is simply the reciprocal of return period. For annual hydrograph approach, individual monthly average discharge covering the length of period is taken as inputs in this study. It represents the variation of a water flow quantity (discharge or stage) with respect to time.

With the help of mass curve, Gumbel's statistical method and annual hydrograph, the apparent change and trend of flow are suggested from the output. With that, correlation between variation of streamflow and climate change can then be identified. 


\section{RESUlTS \& ANALYSIS}

A break in the slope of the mass curve means that a change in the constant of proportionality between the two variables has occurred or perhaps that the proportionality is not a constant at all rates of cumulation. Difference in slope of the line on either side of the break tells the degree of change in the relation. In this study, mass curves with cumulative of annual peak streamflow versus years were plotted to estimate changes in regression slope. From the generated streamflow mass curve (Figure 1), climate change is believed to occur in Sungai Sarawak Basin as it shows that Stations Rayu, Git and Buan Bidi started straying in year 1998, 2001 and 2004 respectively. Both Stations Rayu and Buan Bidi show sharp declination from the original plotting, except Station Git that drops gradually. This claim for Station Git can be based on channel modification due to human activities on Sarawak River Left Tributary. Manmade marvels have increased the flow on the Sarawak River Left Tributary indirectly [9] - [11], which is then producing the outstanding gentle drop trend in Station Git at the upstream of the tributary. Other than that, water source for Sarawak River Left Tributary is originated from Banjaran Bungoh with its highest elevation stands at $800 \mathrm{~m}$, referring topography map (Figure 2). When urbanization started actively at the downstream area of Station Git, it blocks the water from flowing downward. Simultaneously, when there is a large amount of water flowing from 3 tributaries (Table 3 ) connected from mountainous region, this poses flood risk easily.

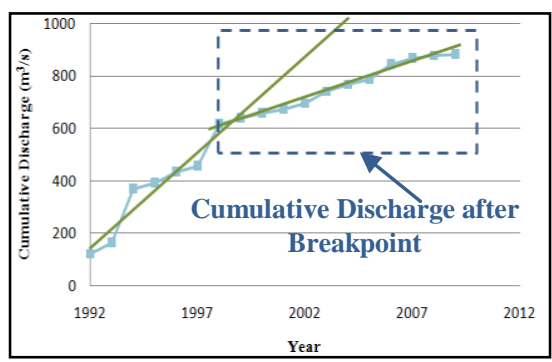

Station Rayu

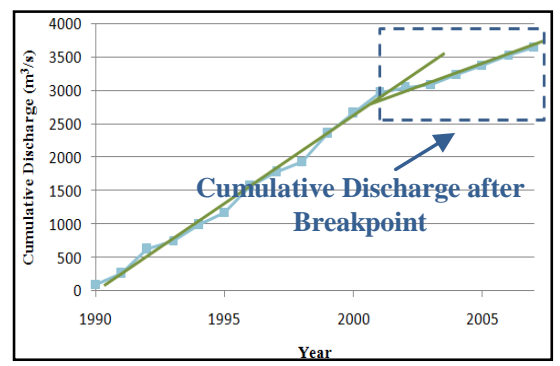

Station Git

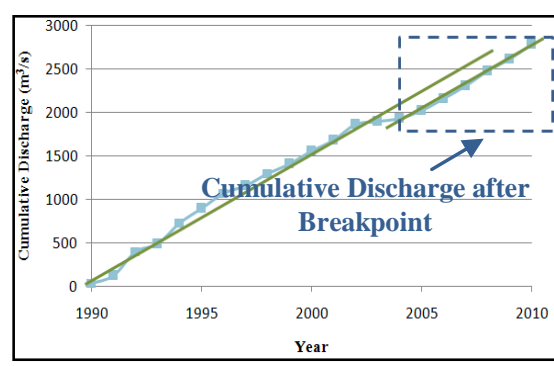

Station Buan Bidi

Figure 1: Mass Curves Plotted for Selected Stations
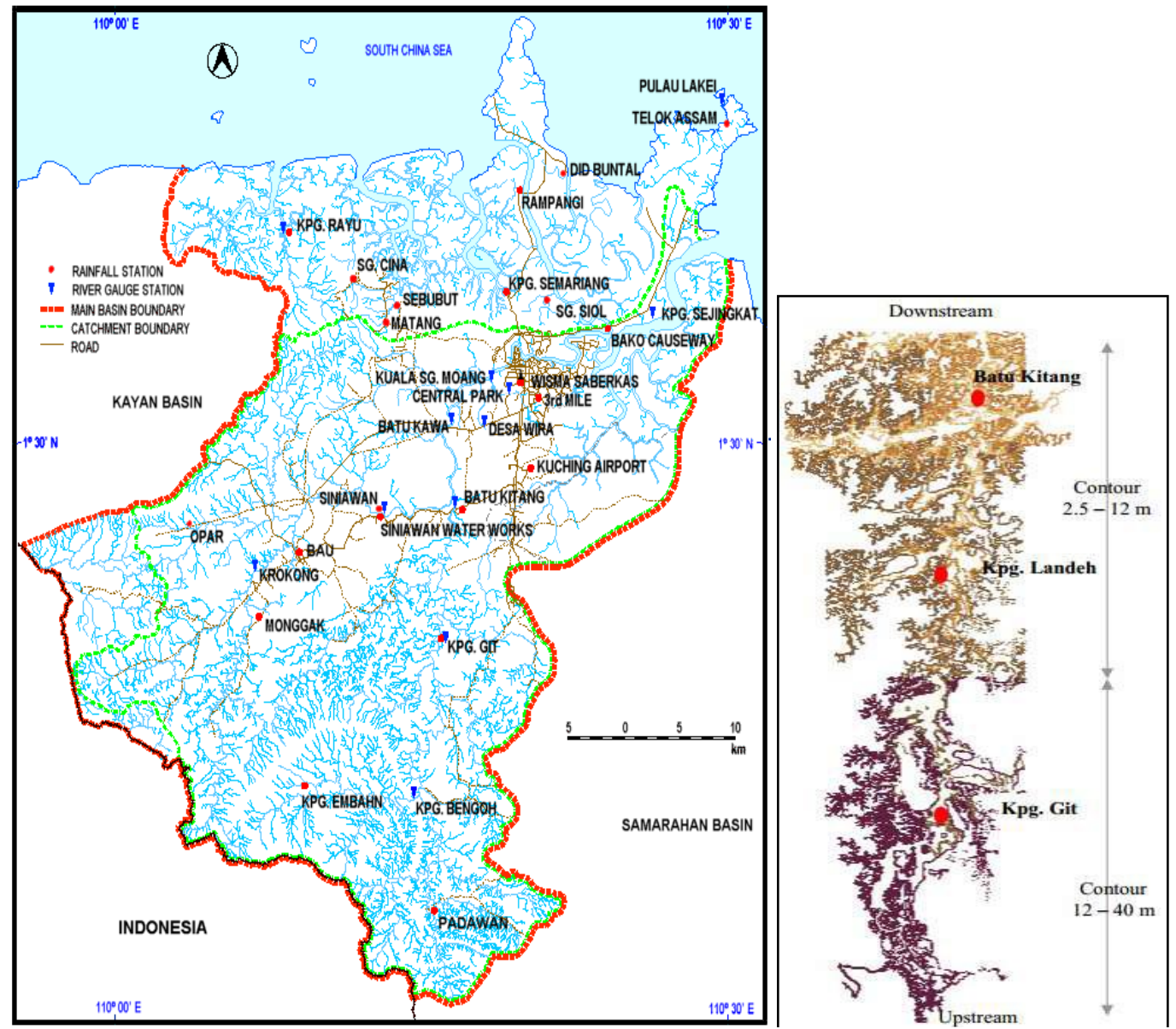

Figure 2: Sg Sarawak River Basin and Contour Map of Sarawak River Left Tributary Basin [15] - [12] 
UNIMAS e-Journal of Civil Engineering: Volume 4, Issue 3

Table 3: Number of Tributaries Observed from Topography Map

\begin{tabular}{cc}
\hline Station & Number of Upstream Tributaries \\
\hline Rayu & 2 \\
Git & 3 \\
Buan Bidi & 2 \\
\hline
\end{tabular}

Tangling result found from Gumbel's statistical method against chance percent in Station Buan Bidi can be claimed upon rate of submergence at Batu Kawa (representative of Station Buan Bidi) of 0.7 - $1.9 \mathrm{~km} / \mathrm{hr}$ [14]. Meaning that, a small amount of precipitation can bring a high stage level in Buan Bidi within a short duration. Intentionally, high rate of submergence has lead to the abnormal discharge (range from $88 \mathrm{~m} / \mathrm{s}$ to $140 \mathrm{~m} / \mathrm{s}$ ) as indicated in dotted circle in Figure 3 .

Besides, as can be seen from Gumbel's statistical method against return period (Figure 4), gaps of difference are getting bigger towards the end for all stations. This condition simply represents the ongoing changes. High flow has tended to decrease at a faster rate with its occurrence frequency sharply decreases inversely, low flow decreases at a slower rate with its occurrence frequency gently decreases. Contemporary drawdown in both high-flow and low-flow observed can be explained by the global warming fact as "dry getting drier, wet getting wetter". Thus, more low flow is expected in the coming future.

Apart from that, a homogeneous pattern is found between annual hydrographs plotted and the general rainfall pattern reported (Figure 5) with low-flow stream at Station Rayu (Figure 6) that shows a dramatic decrease in flow after the change. This finding matches with the theory in reference [3] stating that "precipitation increases caused greater high flows in streams, while temperature increases caused bigger reductions in lowflows". Thereby, the dramatic average discharge drop may imply the possibility of temperature-induced change.

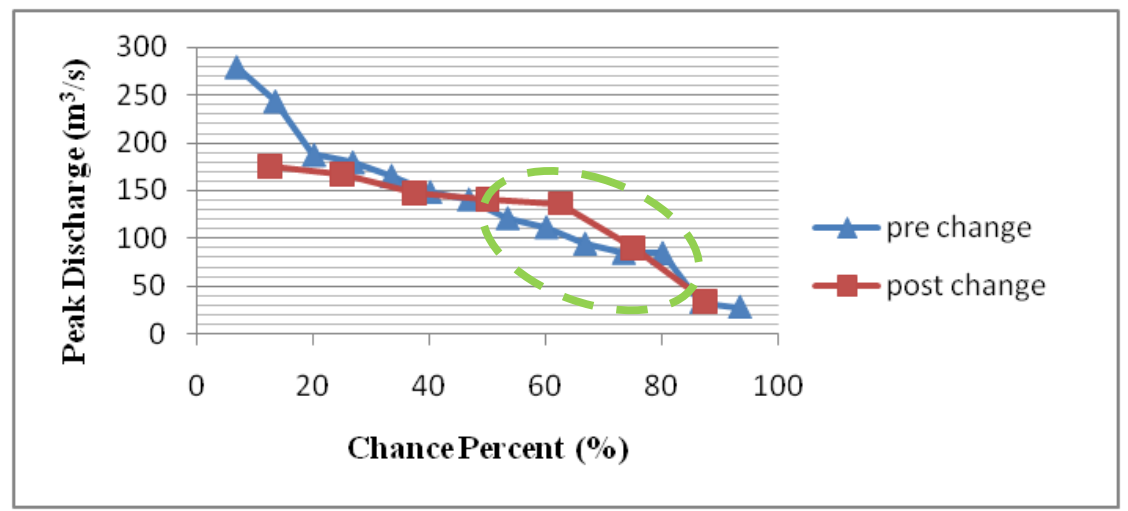

Figure 3: Abnormal Higher Rate of Peak Discharge Occurrence at Station Buan Bidi

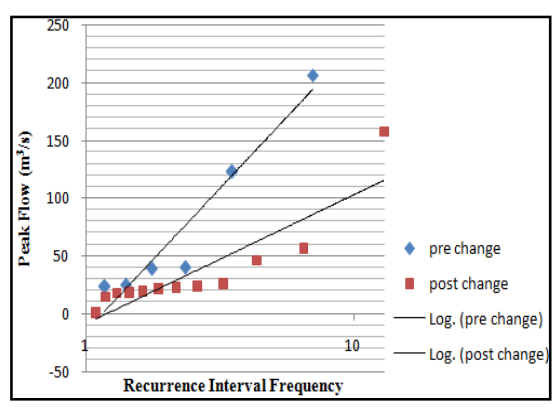

Station Rayu

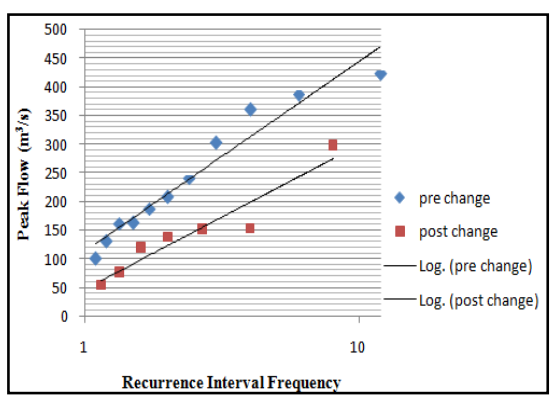

Station Git

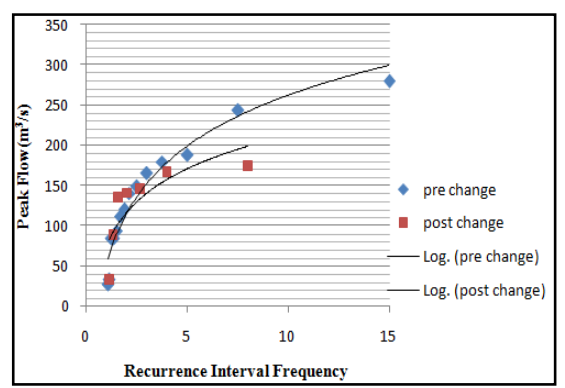

Station Buan Bidi

Figure 4: Gumbel's Statistical Method (Recurrence Interval Frequency) 


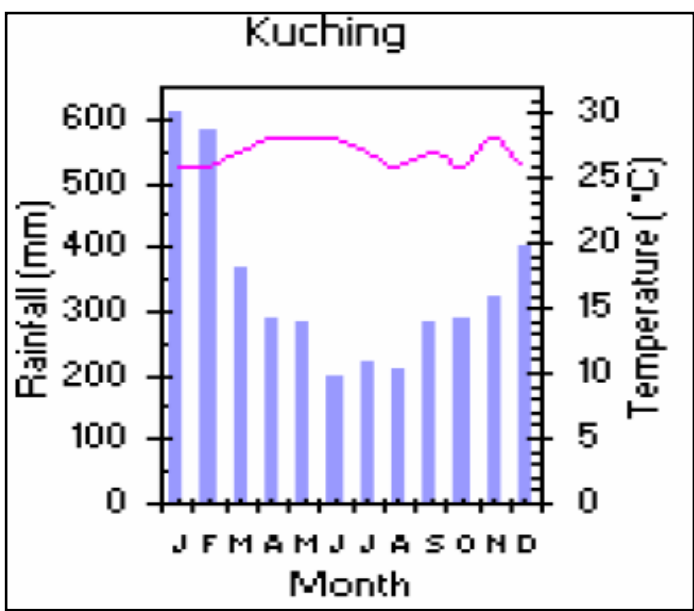

Figure 5: Monthly Rainfall and Temperature Variations for Kuching [13]

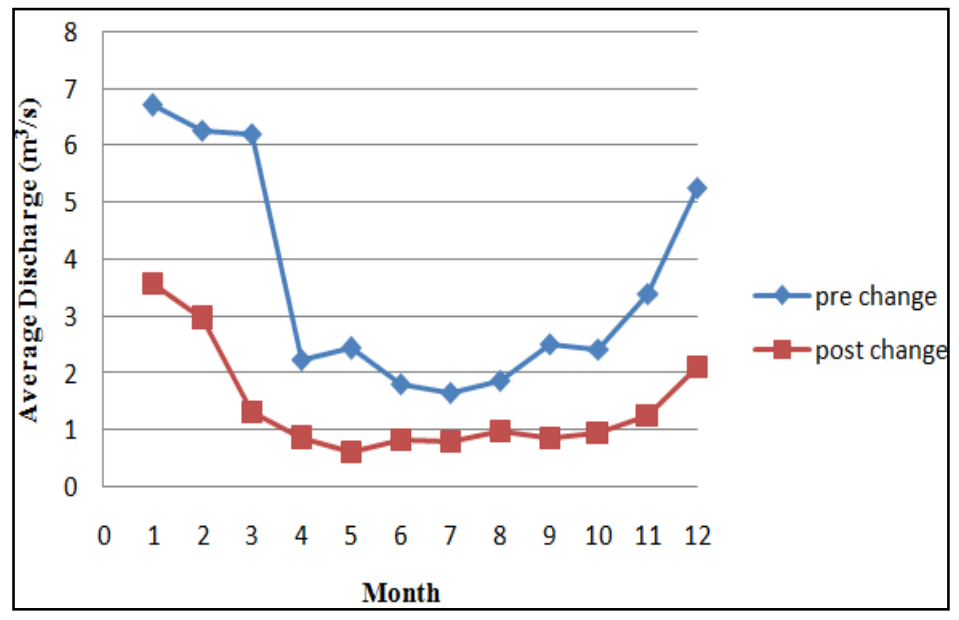

Figure 6: Annual Hydrograph at Station Rayu

Others, it is important to explain on the decreasing trend in high flow which is contradicting with more frequent flood events recorded after the transition year. Annual maximum series which are the most common type of series used in flood frequency analysis are established. Unfortunately, the annual maximum series contain information only on the largest peak flows from every year, which are not necessarily all floods. It may happen that the second (or third, etc.) largest value from a wet year represents severe flood and is larger than annual maximum in a dry year; that kind of information on floods is lost in the annual maximum series.

\section{CONCLUSION}

Climate change is becoming a great issue, in which availability of water and excessive of water in years to come can doubt. Parameters such as precipitation, temperature and evaporation become main variable discharge changes of the water basin which have been influenced by climate change. With the help of graphical probabilistic method, mass curve method and annual hydrograph, authors suggest that Sarawak River Basin is facing shrinkage in water flow. Thence, climate change does take place in Sarawak River Basin with discharge declining over the years gradually.

\section{ACKNOWLEDGMENT}

The authors would like to acknowledge the Department of Irrigation and Drainage (DID), Kota Samarahan for providing the data and technical supports for the accomplishment of this study.

\section{REFERENCES}

[1] Hashim, H.Z., 2010. National Seminar On Meteorology: "Enhancing Weather And Climate Services". Development of Atmospheric Based Flood Forecasting and Warning System for Selected River Basins in Malaysia. Water Resources. Management and Hydrology \& Department of Irrigation and Drainage Malaysia. 9 November 2010, Kuala Lumpur.

[2] Department of Irrigation and Drainage (DID), Sarawak. Sarawak Major River Basin. Available at: http://www.did.sarawak.gov.my/modules/web/page.php?id=315\&menu_id=0\&sub_id=314

[3] EPA United States Environmental Protection Agency, 2012. Climate Change Indicators in the United States 2nd Edition.

[4] Hegerl, G.C., Zwiers, F.W., Braconnot, P., Gillett, N.P., Luo, Y., Marengo Orsini, J.A., Nicholls, N., Penner, J.E., and Stott, P.A., 2007: Understanding and Attributing Climate Change. In: Climate Change 2007: The Physical Science Basis. Contribution of Working Group I to the Fourth Assessment Report of the Intergovernmental Panel on Climate Change [Solomon, S., Qin, D.,Manning, M., Chen, Z., Marquis, M., Averyt, K.B., Tignor, M., and Miller, H.L.,(eds.)]. Cambridge University Press, Cambridge, United Kingdom and New York, NY, USA.

[5] Gaeumana, D., Schmidtb, J.C., and Wilcock, P.R., 2004. Complex Channel Responses to Changes in Stream Flow and Sediment Supply on the Lower Duchesne River, Utah. Science Direct: Geomorphology 64 (2005) 185 - 206.

[6] Jones, J.A., Creed, I.F., Hatcher, K.L., Warren, R.J., Adams, M.B., Benson, M.H., Boose, E., Brown, W.A., Campbell, J.L., Covich, A., Clow, D.W., Dahm, C.N., Elder, K.,Ford, C.R., Grimm, N.B., Henshaw, D.L., Larson, K.L., Miles, E.S., Miles, K.M., Sebestyen, S.D., Spargo, A.D., Stone, A.B., Vose, J.M., and Williams, M.W., 2012. Ecosystem Processes and Human Influences Regulate Streamflow Response to Climate Change at LongTerm Ecological Research Sites. American Institute of Biological Sciences

[7] Chow, V.T., Maidment, D.R., and Mays, L.W., 1988. Applied Hydrology. Singapore: McGraw-Hill.

[8] Al-Mashidani, G., Pande, B.B.LAL and Mujda, M.F., 1978. A Simple Version of Gumbel's Method for Flood Estimation. Hydrological SciencesBulletin-des Sciences Hydrologiques, 23, 3, 9/1978. Mosul, Iraq: University of Mosul.

[9] Hii, C.P., Putuhena, F.J. and Said, S., 2006. Proceedings of Conference on Natural Resources in the Tropics: Development and Commercialization of Tropical Natural Resources, Kuching: The benefit of River Basin Development Approach in Land Use Planning and Management: A review of Kuching City and Its Surrounding Areas Development.

[10] Said, S., Putuhena, F.J., Mah, Y.S., and Lai, S.H., 2008. Proceedings of EnCon2008 2nd Engineering Conference on Sustainable Engineering Infrastructures Development \& Management, Kuching, Sarawak, Malaysia: Modeling of a Hydraulic Structure: Batu Kitang Submersible Weir in Kuching, Sarawak.

[11] Yusuff, M.T.M., O.H. Ahmed and N.M.A. Majid, 2009. Effect of Enhancing Urea- Humic Acid Mixture with Refined Acid Sulphate Soil. Am. J. Applied Sci., 6: 1892-1896. 
UNIMAS e-Journal of Civil Engineering: Volume 4, Issue 3

[12] US Army Corps of Engineers (USACE), 1990. Engineering and Design - Design of Sheet Pile Cellular Structures Cofferdams and Retaining Structure.

[13] Urban Stormwater Management Manual, 2000. Part A: Introduction: Malaysian Perspective. Department of Irrigation and Drainage Malaysia (DID).

[14] Hii, C. P., Putuhena, F.J., Said, S., 2009. International Journal of Hydro-Climatic Engineering, Assoc. Water and Enviro-Modeling: Adaptive Logical Framework for Integrated Flood Management along Sarawak River Centre of Water Research. pp 17 - 36. eISSN : 99990001

[15] Department of Irrigation and Drainage (DID), Sarawak. Sg. Sarawak River Basin. Available at: http://www.did.sarawak.gov.my/rbis/map-html/basinmap.html 